Bojana Jovanović1, Boris Delibašić

'Iritel a.d. Belgrade, Serbia

2 University of Belgrade, Faculty of organizational sciences, Serbia

\title{
Application of integrated QFD and fuzzy AHP approach in selection of suppliers
}

UDC: $005.311 .12: 519.8 ; 658.7: 621.3 .04$

DOI: 10.7595/management.fon.2014.0018

\begin{abstract}
Supplier selection is a widely considered issue in the field of management, especially in quality management. In this paper, in the selection of suppliers of electronic components we used the integrated QFD and fuzzy AHP approaches. The QFD method is used as a tool for translating stakeholder needs into evaluating criteria for suppliers. The fuzzy AHP approach is used as a tool for prioritizing stakeholders, stakeholders' requirements, evaluating criteria and, finally, for prioritizing suppliers. The paper showcases a case study of implementation of the integrated QFD and fuzzy AHP approaches in the selection of the electronic components supplier in one Serbian company that produces electronic devices. Also presented is the algorithm of implementation of the proposed approach. To the best of our knowledge, this is the first implementation of the proposed approach in a Serbian company.
\end{abstract}

Keywords: QFD; fuzzy AHP; fuzzy numbers; supplier selection; stakeholders.

\section{Introduction and literature review}

Limited business resources and a fierce market competition require quality management which considers stakeholders' needs. For every production company important stakeholders are suppliers of components embedded in the final product. The selection of suppliers of product components plays a very important role in the realization of the production process. Supplier selection is a multi-criteria decision-making problem which often consists of qualitative metrics. Many authors presented different approaches in supplier selection. Variants of the integrated QFD (quality function deployment) methods (Ju \& Hwang, 2004) have been used in selecting and ranking suppliers. For example, a supplier selection methodology based on QFD and data mining technique has been proposed (Ni et al., 2007). Many researchers have proposed the introduction of fuzzy numbers in the QFD approach for the supplier selection process (Bevilacqua et al., 2006). Gencer \& Gurpinar (2007) proposed a model for usage of an analytic network process (ANP) in supplier selection. \& (2009) published a paper about the Internet service provider selection, using fuzzy numbers in combination with the QFD method. Kilincci \& Onal (2011) presented one supplier selection problem of a washing machine company in Turkey that used a fuzzy analytic hierarchy process (AHP) methodology. Zouggari \& Benyoucef (2012) presented an approach for the supplier selection problem, using the fuzzy TOPSIS (Technique for Order of Preference by Similarity to Ideal Solution) technique.

Many papers present separated integrated fuzzy AHP and fuzzy QFD approaches, but there are only several papers which present integrated QFD and fuzzy AHP approaches as one technique. To the best of our knowledge, no selection of suppliers of electronic components using integrated QFD and fuzzy AHP approaches has been published up to now. One integrated QFD and fuzzy AHP approach and its application is presented in this paper. This is the first application of QFD and fuzzy AHP in a Serbian company. The detailed algorithm of application of the proposed approach is given in Chapter 3.

The proposed approach allows for an integration of requirements of different stakeholders in decision making about the supplier selection. A pilot research is conducted in one company which is a manufacturer of electronic devices. 
The reminder of the paper will be organized as follows. In Chapter 2, the QFD method, the fuzzy QFD method and the fuzzy AHP approach, with their applications in available literature are described. In Chapter 3, the implemented integrated QDF and fuzzy AHP approaches are described and necessary guidelines for its practical implementation are given. In Chapter 4, a case study of implementation of the integrated QFD and fuzzy AHP approach in the selection of the electronic components supplier in one Serbian company that produces electronic devices are showcased. In Chapter 5, the result analysis, conclusions and future research proposals are described.

\section{QFD, fuzzy and AHP approaches}

The QFD method originated in 1972 in Japan, as a methodology for improving products quality in Japanese firms (Hauser \& Clausing, 1988). One of the benefits of the QFD method is that it takes into consideration the stakeholders' needs (Akao, 1990). The process of QFD involves the construction of one or more interlinked matrices, "Houses of Quality" (HoQs). During the QFD process, the determination of the importance weights of stakeholders' requirements is an essential step ( \& 2003). Some authors have integrated QFD with other methods. Chen \& Ngai (2008) proposed a fuzzy-QFD approach. Lee et al. (2008) integrated the Kano model with the Fuzzy mode into the matrix of the QFD. Delice \& Zülal (2009) combined the QFD with an integer linear programming model and the Kano model. Liang (2010) developed an approach of a fuzzy-QFD. Another variant for the integration of the QFD model is the AHP technique. There have been huge efforts to integrate AHP with QFD in order to identify the priority of customer requirements (Chuang, 2001; Bhattacharya et al., 2005). In recent years, the QFD has been used in different areas. Karsak et al. (2002) used the QFD for product planning. Luo et al. (2008) used the QFD method for components selection. Chaudhuria \& Bhattacharyya (2009) linked the QFD with the Conjoint Analysis to determine technical characteristics. Chen (2009) integrated the QFD with the process management in product design improvement. Deros et al. (2009) proposed a QFD method for measuring the service quality characteristics. Chuang at al. (2009) used the QFD method to provide the market trends, competitive and operational strategies.

Zadeh (1965) introduced the fuzzy set theory to deal with the uncertainty. The motivation for the use of words or sentences rather than numbers is that linguistic characterizations are less specific than numerical ones (Zadeh, 1973). The fuzzy logic allows for decision-making with estimated values under incomplete information. The integrated fuzzy QFD approach is used in many different areas, for example, in ensuring reliability in supply chain management (Sohn \& Choi, 2001), in evaluation in building industry (Yang et al., 2003), in an industrial company which supplies motors for electronic appliance companies (Erol \& Ferrell, 2003), in ranking the strategic actions of the Iran mobile cellular telecommunications (Khademi-Zare et al., 2010), in routing of shipping investment decisions in crude oil tanker market (Celik et al., 2009), in environmental considerations (Kuo et al., 2009), in acquiring enterprise software selection requirements (Sen \& Baracli, 2010), in characterizing customers' rating of extra virgin olive oil (Bevilacqua et al., 2012), as a decision support model for licensor selection (Wang et al., 2012).

The analytic hierarchy process (AHP) has been developed by Saaty $(1977,1980)$. The methodology tradesoff among various qualitative and quantitative factors with a scale called Saaty's ninepoint scale (Saaty, 1980, $1988,2008)$. In the research of literature, it is observed that the focus has been on the applications of the integrated AHP rather than the stand-alone AHP. The methods and techniques which are commonly combined with the AHP include mathematical programming, quality function deployment (QFD), meta-heuristics, the SWOT analysis, and the data envelopment analysis (DEA) (, 2008). The fuzzy AHP approach is implemented in many different business areas, such as a strategic analysis of healthcare service quality (Buyukozkan et al., 2011), in shipping registry selection in the Turkish maritime industry (Celik et al., 2009), in prioritization of attributes in target planning for automotive product development (Nepal et al., 2010), in evaluating environmental sustainability from the perspective of the "Secured by Design" scheme (Larimian et al., 2013), in work safety evaluation and early warning rating of hot and humid environments (Zheng et al., 2012), in the evaluation of recreational fishing (Gao \& Hailu, 2012), in risk assessment of implementing green initiatives in the fashion supply chain (Wang et al., 2012), in multi-criteria supplier segmentation (Rezaei \& Ortt, 2013), in the strategic analysis of electronic service quality in healthcare industry (Buyukozkan \& Cifci, 2012), in timetable evaluation (Isaai et al., 2011), in managing intellectual capital assets and an application to the ICT service industry (Calabrese et al., 2013), in prioritizing customer requirements in QFD (Kwong \& Bai, 2006). Ho et al. (2012) presented an integrated QFD and fuzzy AHP approach and its application in strategic logistics outsourcing. 


\section{Integrated QFD and fuzzy AHP approach}

The integrated QFD and fuzzy AHP approach which is implemented in this paper includes three "Houses of Quality" (HOQs), including HOQ1 which links company stakeholders with their requirements, HoQ2 which relates stakeholder requirements to suppliers evaluating criteria, and HoQ3 which benchmarks alternative suppliers with respect to various criteria. Each pairwise comparison result in an AHP matrix or HoQ is a fuzzy number which possesses the characteristics of a triangular fuzzy membership function (Ho et al., 2012). In the case study in this paper, the integrated QFD and fuzzy AHP approach, proposed by Ho et al. (2012) and Calabrese et al., (2013) is used. We adopted a triangular fuzzy conversation scale proposed by Chang (1996), given in Table 1. For defuzzification, we used the central deffuzification method.

Table 1: Triangular fuzzy conversation scale (Chang, 1996)

\begin{tabular}{|c|c|c|}
\hline Linguistic scale & $\begin{array}{c}\text { Triangular fuzzy } \\
\text { conversation scale }\end{array}$ & $\begin{array}{c}\text { Triangular fuzzy } \\
\text { reciprocal scale }\end{array}$ \\
\hline JUST EQUAL (1) & $(1,1,1)$ & $(1,1,1)$ \\
\hline EQUALLY important (2) & $(1 / 2,1,3 / 2)$ & $(2 / 3,1,2)$ \\
\hline WEAKLY MORE important (3) & $(1,3 / 2,2)$ & $(1 / 2,2 / 3,1)$ \\
\hline MODERATERLY MORE important $(4)$ & $(3 / 2,2,5 / 2)$ & $(2 / 5,1 / 2,2 / 3)$ \\
\hline STRONGLY MORE important (5) & $(2,5 / 2,3)$ & $(1 / 3,2 / 5,1 / 2)$ \\
\hline EXTREMELY MORE important (6) & $(5 / 2,3,7 / 2)$ & $(2 / 7,1 / 3,2 / 5)$ \\
\hline
\end{tabular}

The numbers used in the comparison scale (given in Table 1) have the following meanings:

- 1 - JUST EQUAL -Both subjects have the same significance

- 2 - EQUALLY IMPORTANT - Subject on the left side of the scale is equally important as the subject on the right-hand scale

- 3 - WEAKLY MORE IMPORTANT - Subject on the left side of the scale is weakly more important than the subject on the right-hand scale

- 4 - MODERATERLY MORE IMPORTANT - Subject on the left side of the scale is moderately more important than the subject on the right-hand scale

- 5 - STRONGLY MORE IMPORTANT - Subject on the left side of the scale is strongly more important than the subject on the right-hand scale

- 6 - EXTREMELY MORE IMPORTANT - Subject on the left side of the scale is extremely more important than the subject on the right-hand scale

Prior to the implementation of the method, AHP questionnaires were prepared. We made a pilot research, using the created AHP questionnaires, with answers in fuzzy numbers. We had four groups of AHP questionnaires (for prioritization of stakeholder importance, for prioritization of stakeholder requirements, for prioritization of evaluating criteria and for prioritization of alternative suppliers). For computing priorities on the basis of questionnaires, a fuzzy AHP is used. All priorities are prescribed in three HoQs. In the first step, the management team establishes the importance of stakeholders in decision-making. After that, each of the stakeholders completed one questionnaire which determined the priority of the stakeholder requirements. Afterwards, a team comprised of stakeholders completed one questionnaire, which determined the priority of the criteria for the evaluation of suppliers. And finally, again, the same team consisting of stakeholders, completed one questionnaire, which evaluates suppliers in respect of all criteria. In Figure 1 the algorithm of the implemented approach is given. 


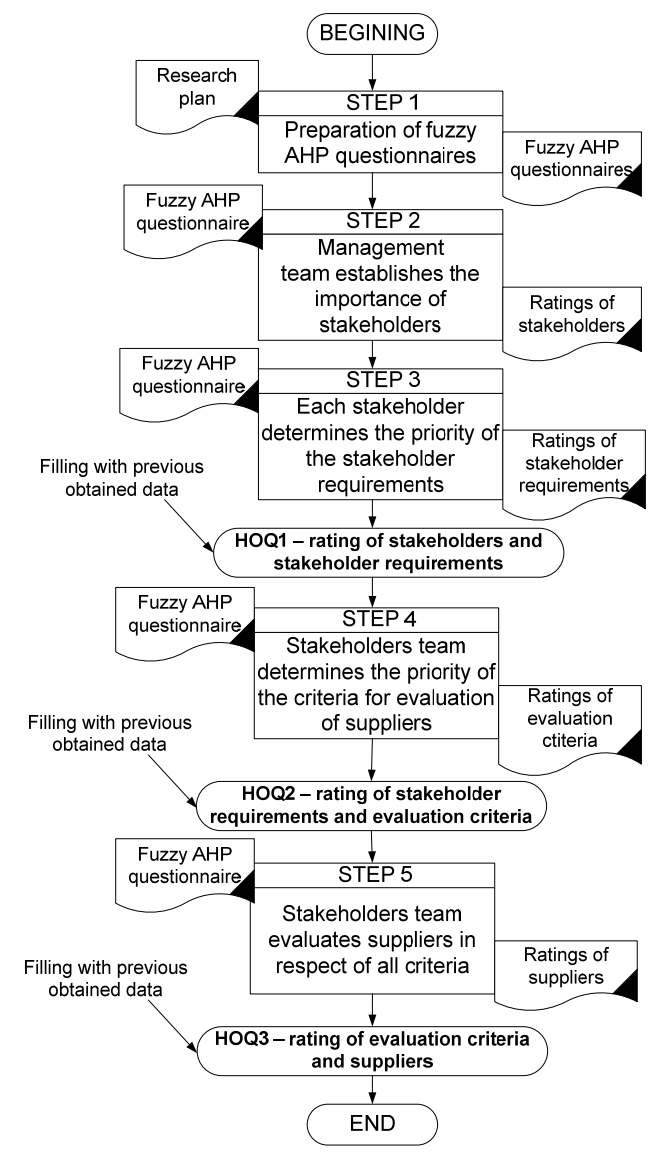

Figure 1: Algorithm of integrated QFD and fuzzy AHP approach

\section{Case study of implementation of integrated QFD and fuzzy AHP approach on selection of electronic components supplier}

The company that is the subject of our case study is one Serbian enterprise that produces electronic devices and has its own research and development institute. The company's main business activities are: research \& development, design, manufacturing, engineering, consulting, maintenance, technical and customer training. The company is paying great attention to the selection and evaluation of suppliers of electronic components. In accordance with the implemented and certified quality management system, the company has to evaluate potential suppliers. The integrated QFD and fuzzy AHP method allows the company to include stakeholder requirements in the process of evaluation and selection of suppliers. One possible method for evaluation and selection of suppliers of electronic components is proposed.

Stakeholders who influence the selection of suppliers are: procurement manager, marketing manager, product development manager and production manager. The structure of the AHP model is given in Figure 2.

Identified requirements of stakeholders (conducted brainstorming sessions):

- Appropriate delivery conditions

- Possession of certified management systems

- Guarantees for the execution of delivery and services within the warranty period

The authors Ho et al. (2012) used the following criteria in evaluating suppliers of third-party logistics services: cost, delivery, flexibility, quality, technology and risk. Supplier selection attributes according to $\mathrm{Ha} \& \mathrm{Kr}-$ ishnan (2008) framework are the following: after sales service, geographical location, product appearance, 
amount of past business, impression, production facilities and capacity, attitude, Just-In-Time capability, quality, catalogue technology, labour relations, reciprocal arrangements, communication system, maintainability, reputation and position in industry, delivery, management and organization, response to customer request, ease-of-use, operational controls, technical capability, e-commerce capability, packaging ability, technical support, environmentally friendly products, performance history, training aids, financial position, price, warranties and claims. Identified criteria for evaluation of suppliers, in accordance with the requirements of stakeholders (conducted brainstorming sessions) are the following:

- Delivery conditions: delivery time, price, distance of supplier, adaption to customer needs (emergency supplies, smaller lots, etc.), discounts (quantity, loyal customers, etc.).

- Management systems: courtesy of staff, packaging and transport conditions, previous customer experience, experience in communication with staff, number of certified management systems.

- Warranties: financial stability, complaints procedure, warranty period.

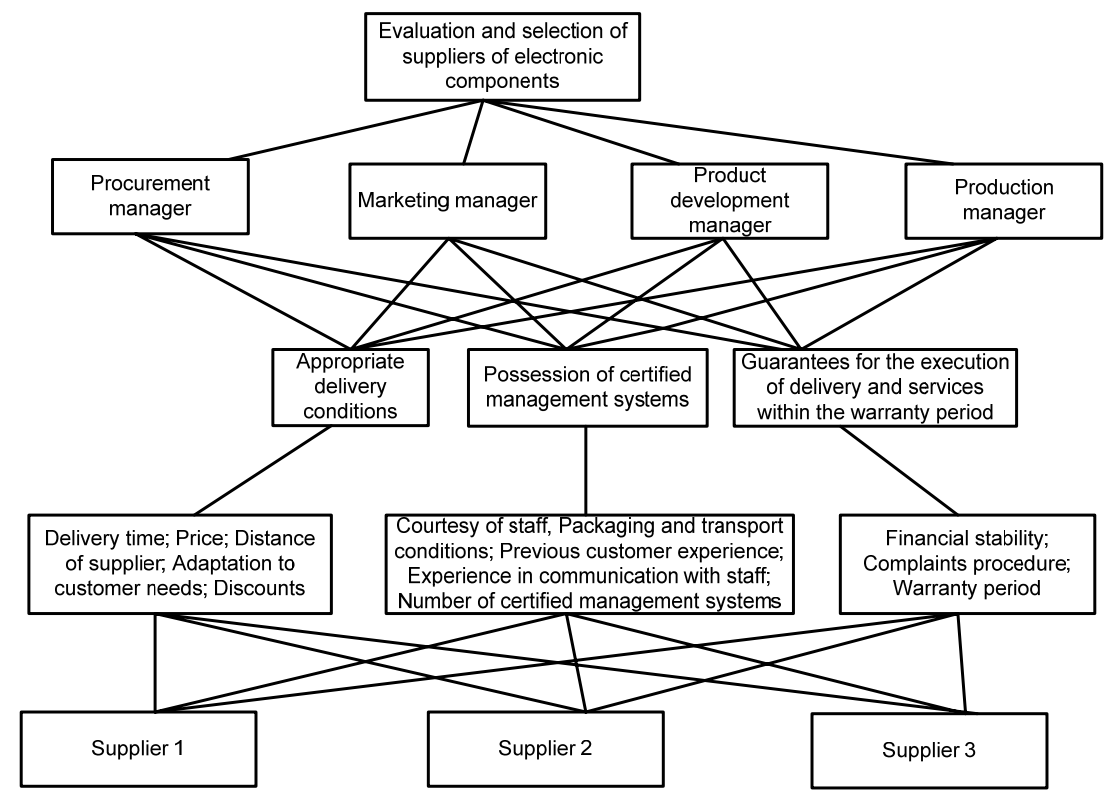

Figure 2: Fuzzy AHP model: goal, criteria, sub-criteria and alternatives

All results obtained in the research are systematizes in three HoQs, shown in Table 2, Table 3 and Table 4. The first HoQ (HoQ1) represents the stakeholders involved in the selection of suppliers of electronic components, their importance in the process of selection of suppliers and stakeholder requirements. The HoQ1 allow us to compute the importance of each stakeholder's requirements, which will then be used in the HoQ2.

Table 2: HoQ1 - Stakeholders and stakeholder's requirements

\begin{tabular}{|c|c|c|c|c|}
\hline & 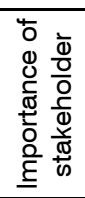 & 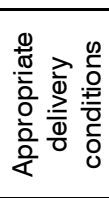 & 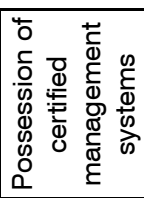 & 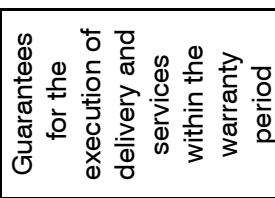 \\
\hline Procurement manager & 0.349 & 0.319 & 0.361 & 0,319 \\
\hline Marketing manager & 0.206 & 0.298 & 0.431 & 0,27 \\
\hline Product development manager & 0.222 & 0.319 & 0.361 & 0,319 \\
\hline Production manager & 0.222 & 0.42 & 0.289 & 0,289 \\
\hline \multicolumn{2}{|c|}{$\begin{array}{l}\text { IMPORTANCE OF STAKEHOLDER } \\
\text { REQUIREMENTS: }\end{array}$} & 0.3367 & 0.3591 & 0.3019 \\
\hline
\end{tabular}


The second HoQ (HoQ2) represents the stakeholder requirements, defined at the brainstorming session, their importance for each stakeholder and the criteria for the evaluation of suppliers (defined at the brainstorming session). The HoQ2 allow us to compute the importance of each evaluating criteria, which will be used in the next HoQ3.

Table 3: HoQ2 - Stakeholder's requirements and evaluating criteria

\begin{tabular}{|c|c|c|c|c|c|c|c|c|c|c|c|c|c|c|}
\hline HoQ2 & 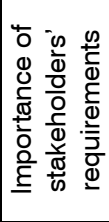 & 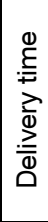 & $\frac{0}{0}$ & 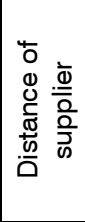 & 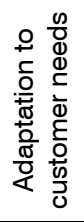 & 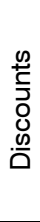 & 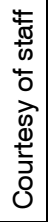 & 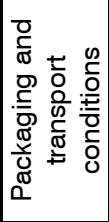 & 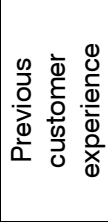 & 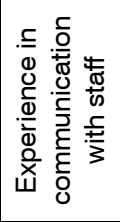 & 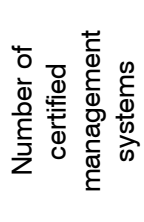 & 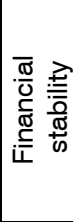 & 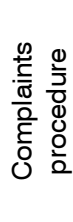 & 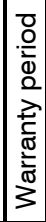 \\
\hline $\begin{array}{l}\text { Appropriate } \\
\text { delivery } \\
\text { conditions }\end{array}$ & $\begin{array}{c}\hat{m} \\
\text { ले }\end{array}$ & $\frac{\text { மீ }}{\frac{0}{0}}$ & 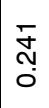 & 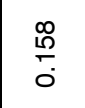 & $\frac{\pi}{\frac{\pi}{0}}$ & 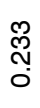 & & & & & & & & \\
\hline $\begin{array}{l}\text { Possession of } \\
\text { certified } \\
\text { management } \\
\text { systems } \\
\end{array}$ & 怘 & & & & & & 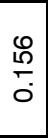 & 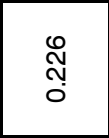 & $\begin{array}{l}\mathscr{P} \\
\stackrel{N}{0}\end{array}$ & $\stackrel{N}{o}$ & $\stackrel{\infty}{\infty}$ & & & \\
\hline $\begin{array}{l}\text { Guarantees for } \\
\text { the execution of } \\
\text { delivery and } \\
\text { services within } \\
\text { the warranty } \\
\text { period }\end{array}$ & ס్ల్ & & & & & & & & & & & ্ָণ & $\begin{array}{l}\text { @् } \\
\text { ले } \\
0\end{array}$ & \begin{tabular}{|l|}
9 \\
0 \\
0 \\
0 \\
0
\end{tabular} \\
\hline \multicolumn{2}{|c|}{$\begin{array}{l}\text { IMPORTANCE OF } \\
\text { EVALUATING CRITERIA: }\end{array}$} & 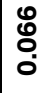 & $\begin{array}{l}\bar{\infty} \\
0 \\
0\end{array}$ & గొ & $\begin{array}{l}\text { 융 } \\
\text { 옹 }\end{array}$ & $\begin{array}{l}\infty \\
\stackrel{\infty}{0} \\
0\end{array}$ & $\begin{array}{l}\mathscr{0} \\
\stackrel{0}{0} \\
0\end{array}$ & 亦 & $\begin{array}{l}\stackrel{1}{\infty} \\
0 \\
0\end{array}$ & $\begin{array}{l}\text { N } \\
\text { O } \\
0\end{array}$ & $\begin{array}{l}\text { L̊ } \\
0 \\
0\end{array}$ & 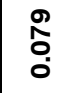 & $\frac{F}{\sigma}$ & $\frac{\sigma}{\sigma}$ \\
\hline
\end{tabular}

The third $\mathrm{HoQ}$ (HoQ3) represents evaluating criteria, their importance in the evaluation of suppliers, and the suppliers which will be evaluated. The HoQ3 allow us to compute the importance of each supplier.

Table 4: HoQ3 - Evaluating criteria and suppliers

\begin{tabular}{|c|c|c|c|c|}
\hline HoQ3 & 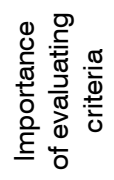 & 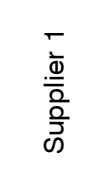 & 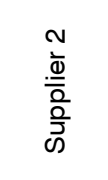 & 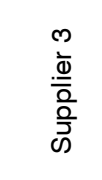 \\
\hline Delivery time & 0.066 & 0.421 & 0.29 & 0,29 \\
\hline Price & 0.081 & 0.302 & 0.315 & 0,384 \\
\hline Distance of supplier & 0.053 & 0.37 & 0.37 & 0,261 \\
\hline Adaptation to customer needs & 0.059 & 0.37 & 0.261 & 0,37 \\
\hline Discounts & 0.079 & 0.261 & 0.37 & 0,37 \\
\hline Courtesy of staff & 0.056 & 0.333 & 0.333 & 0,333 \\
\hline Packaging and transport conditions & 0.081 & 0.34 & 0.321 & 0,34 \\
\hline Previous customer experience & 0.085 & 0.37 & 0.261 & 0,37 \\
\hline Experience in communication with & 0.072 & 0.368 & 0.341 & 0,291 \\
\hline Number of certified management & 0.065 & 0.228 & 0.393 & 0,379 \\
\hline Financial stability & 0.079 & 0.333 & 0.333 & 0,333 \\
\hline Complaints procedure & 0.111 & 0.37 & 0.261 & 0,37 \\
\hline Warranty period & 0.111 & 0.333 & 0.333 & 0,333 \\
\hline \multicolumn{2}{|c|}{ IMPORTANCE OF SUPPLIERS: } & 0.3376 & 0.3181 & 0.3427 \\
\hline
\end{tabular}


After determining all relationship importance, the importance rating of each supplier was computed in the HoQ3 as shown in Table 4. According to the HoQ3, the performance of the supplier 3 is the best, followed by supplier 1 and supplier 2 . Alternatively, the performance of suppliers can be evaluated with respect to groups of evaluation criteria (delivery conditions, management systems and warranties).

\section{Result analysis and conclusions}

In this section, we will benchmark alternative suppliers with respect to groups of evaluating criteria. Each group of criteria will be analyzed to understand which supplier is the best in respect of each group of criteria. Values of importance of suppliers given in Table 5, Table 6 and Table 7 have been normalized. The first group of criteria is "delivery conditions", in which there are five criteria as shown in Table 5. Supplier 3 performs the best in this category because it has discounts for customers, is adaptive to customer needs and offers a competitive price. However, this does not apply to the two criteria, which will lead to a low level of satisfaction because of lengthy delivery time and a large distance of the supplier from the company.

Table 5: Importance of suppliers with respect to group of criteria: delivery conditions

\begin{tabular}{|c|c|c|c|c|}
\hline & $\begin{array}{c}\text { Importance of } \\
\text { evaluating } \\
\text { criteria }\end{array}$ & Supplier 1 & Supplier 2 & Supplier 3 \\
\hline Delivery time & 0.066 & 0.421 & 0.29 & 0,29 \\
\hline Price & 0.081 & 0.302 & 0.315 & 0,384 \\
\hline Distance of supplier & 0.053 & 0.37 & 0.37 & 0,261 \\
\hline Adaption to customer needs & 0.059 & 0.37 & 0.261 & 0,37 \\
\hline Discounts & 0.079 & 0.261 & 0.37 & 0,37 \\
\hline IMPORTANCE OF SUPPLIERS: & $\mathbf{0 . 1 1 4 3 1}$ & $\mathbf{0 . 1 0 8 8 9}$ & $\mathbf{0 . 1 1 5 1 3 7}$ \\
\hline
\end{tabular}

The second group of criteria is "management systems", in which there are five criteria as shown in Table 6. Supplier 3 performs the best in this category because it has courteous staff, good packaging and transport conditions and previous customers have good experience with this supplier. However, this does not apply to the two criteria, which will lead to a low level of satisfaction because of bad experience in communication with the staff (inefficiency in communication) and a smaller number of certified management systems in comparison with supplier 2.

Table 6: Importance of suppliers with respect to group of criteria: management systems

\begin{tabular}{|c|c|c|c|c|}
\hline & $\begin{array}{c}\text { Importance of } \\
\text { evaluating } \\
\text { criteria }\end{array}$ & Supplier 1 & Supplier 2 & Supplier 3 \\
\hline Courtesy of staff & 0.056 & 0.333 & 0.333 & 0,333 \\
\hline Packaging and transport conditions & 0.081 & 0.34 & 0.321 & 0,34 \\
\hline Previous customer experience & 0.085 & 0.37 & 0.261 & 0,37 \\
\hline Experience in communication with staff & 0.072 & 0.368 & 0.341 & 0,291 \\
\hline Number of certified management systems & 0.065 & 0.228 & 0.393 & 0,379 \\
\hline \multicolumn{2}{|c|}{ IMPORTANCE OF SUPPLIERS: } & $\mathbf{0 . 1 1 8 9 5}$ & $\mathbf{0 . 1 1 6 9 3}$ & $\mathbf{0 . 1 2 3 2 2 5}$ \\
\hline
\end{tabular}

The third group of criteria is "warranties", in which there are three criteria as shown in Table 7. Supplier 3 and supplier 2 perform the best in this category because they are financially stable (as other suppliers), have a short and simple procedure for complaints and offer a warranty as other suppliers. 
Table 7: Importance of suppliers with respect to group of criteria: warranties

\begin{tabular}{|c|c|c|c|c|}
\hline & $\begin{array}{c}\text { Importance of } \\
\text { evaluating } \\
\text { criteria }\end{array}$ & Supplier 1 & Supplier 2 & Supplier 3 \\
\hline Financial stability & 0.079 & 0.333 & 0.333 & 0,333 \\
\hline Complaints procedure & 0.111 & 0.37 & 0.261 & 0,37 \\
\hline Warranty period & 0.111 & 0.333 & 0.333 & 0,333 \\
\hline \multicolumn{2}{|c|}{ IMPORTANCE OF SUPPLIERS: } & $\mathbf{0 . 1 0 4 3 4}$ & $\mathbf{0 . 0 9 2 2 4}$ & $\mathbf{0 . 1 0 4 3 4}$ \\
\hline
\end{tabular}

This paper used an integrated QFD and fuzzy AHP approach to measure the performance of suppliers of electronic components, embedded in electronic devices. A case study was presented to demonstrate how this approach can be implemented in the selection of electronic component suppliers. The integrated fuzzy AHP and QFD approach was used to translate the stakeholders' requirements into 13 evaluation criteria which were used to benchmark the suppliers and to determine the importance and weightings in the HoQs. The integrated approach involves a team of people representing various departments that have a say in the selection of electronic component suppliers: procurements, marketing, product development and production. After the implementation of the proposed approach, we can conclude that the company should select supplier 3 , because it has courteous staff, good packaging and transport conditions, previous customers have good experience with this supplier, the supplier grants discounts for customers, it is adaptive to customer needs and has competitive prices, a financial stability, a short and simple procedure for complaints and grants warranty as other suppliers. The detail algorithm of application of the proposed approach is shown in Figure 1, which allows for the reproducibility of the conducted research. The other benefit of this paper is that this is the first application of QFD and fuzzy AHP in a Serbian company. Since this is pilot research, a small sample of respondents is used, and this is the main disadvantage of this paper. A larger sample of respondents would make the findings of our paper more reliable.

\section{REFERENCES}

[1] Akao, Y. (1990). Quality function deployment: Integrating customer requirements into product design, Cambridge, MA: The Productivity Press

[2] , S. H., , J. (2009). An integrated fuzzy model for supplier management: A case study of ISP selection and evaluation, , , Pages 8639-8648, DOI: 10.1016/j.eswa.2008.10.012

[3] Bevilacqua, M., Ciarapica, F. E., Marchetti, B. (2012). Development and test of a new fuzzy-QFD approach for characterizing customers rating of extra virgin olive oil, Food Quality and Preference, 24, 7584, DOI: 10.1016/j.foodqual.2011.09.005

[4] Bevilacqua, M., Ciarapica, F.E., Giacchetta, G. (2006). A fuzzy-QFD approach to supplier selection, Journal of Purchasing \& Supply Management, 12, 14-27, DOI: 10.1016/j.pursup.2006.02.001

[5] Bhattacharya, A., Sarkar, B., Mukherjee, S.K. (2005). Integrating AHP with QFD for robot selection under requirement perspective, International Journal of Production Research, 43 (17), 3671-3685, DOI: 10.1016/j.asoc.2010.05.025

[6] Buyukozkan, G., Cifci, G. (2012). A combined fuzzy AHP and fuzzy TOPSIS based strategic analysis of electronic service quality in healthcare industry, Expert Systems with Applications 39, 2341-2354, DOI: 10.1016/j.eswa.2011.08.061

[7] Buyukozkan, G., Cifci, G., Guleryuz, S. (2011). Strategic analysis of healthcare service quality using fuzzy AHP methodology, Expert Systems with Applications 38, 9407-9424, DOI: 10.1016/j.eswa.2011.01.103

[8] Calabrese, A., Costa, R., Menichini, T. (2013). Using Fuzzy AHP to manage Intellectual Capital assets: An application to the ICT service industry, Expert Systems with Applications, DOI: 10.1016/j.eswa.2012.12.081

[9] Celik, M., Cebi, S., Kahraman, C., Er, I.D. (2009). An integrated fuzzy QFD model proposal on routing of shipping investment decisions in crude oil tanker market, Expert Systems with Applications 36, 62276235, DOI: 10.1016/j.eswa.2008.07.031

[10] Celik, M., Deha, D.I., Ozok, A. F. (2009). Application of fuzzy extended AHP methodology on shipping registry selection: The case of Turkish maritime industry, Expert Systems with Applications 36, 190198, DOI: 10.1016/j.eswa.2007.09.004

[11] Chang, D.Y. (1996). Application of extend analysis method on fuzzy AHP, European Journal of Operational Research, 96, 343-350, DOI: 10.1016/0377-2217(95)00300-2 
[12] Chaudhuria, A., Bhattacharyya, M. (2009). A combined QFD and integer programming framework to determine attribute levels for conjoint study, International Journal of Production Research, 47(23), 66336649, DOI: 0.1007/978-90-481-2860-0_13

[13] Chen, C. C. (2009). Integration of quality function deployment and process management in the semiconductor industry, International Journal of Production Research, 47(6), 1469-1484, DOI: 10.1016/j.cie.2010.01.011

[14] Chen, Y. Z., Ngai, E. W. T. (2008). A fuzzy QFD program modeling approach using the method of imprecision, International Journal of Production Research, 46(24), 6823-6840, DOI: 10.1080/00207540701463297

[15] Chuang, M., Yang, Y. S., Lin, C. T. (2009). Production technology selection: Deploying market requirements, competitive and operational strategies, and manufacturing attributes, International Journal of Computer Integrated Manufacturing, 22(4), 345-355, DOI: 10.1080/09511920802209066

[16] Chuang, P.-T. (2001). Combining the analytic hierarchy process and quality function deployment for a location decision from a requirement perspective, International Journal of Advanced Manufacturing Technology 18, 842-849, DOI: 10.1007/s001700170010

[17] Delice, E. K., Zülal, G. (2009). A new mixed integer linear programming model for product development using quality function deployment, Computers \& Industrial Engineering, 57, 906-912, DOI: 10.1016/j.cie.2009.03.005

[18] Deros, B. M., Rahman, N., Rahman, M. Z. A., Ismail, A. R., Said, A. H. (2009). Application of quality function deployment to study critical service quality characteristics and performance measures, European Journal of Scientific Research, 33(3), 398-410

[19] Erol, I., Ferrell, W.G. (2003). A methodology for selection problems with multiple, conflicting objectives and both qualitative and quantitative criteria, International Journal of Production Economics 86 (3), $187-$ 199, DOI: 10.1016/S0925-5273(03)00049-5

[20] Gao, L., Hailu, A. (2012). Ranking management strategies with complex outcomes: An AHP-fuzzy evaluation of recreational fishing using an integrated agent-based model of a coral reef ecosystem, Environmental Modelling \& Software 31, 3e18, DOI: 10.1016/j.envsoft.2011.12.002

[21] , C., , D. (2007). Analytic network process in supplier selection: A case study in an electronic firm, , , Pages 2475-2486, DOI: 10.1016/j.apm.2006.10.002

[22] Ha, H.S., Krishnan, R., (2008). A hybrid approach to supplier selection for the maintenance of a competitive supply chain, Expert Systems with Applications 34 (2), 1303-1311, DOI: 10.1016/j.eswa.2006.12.008

[23] Hauser, J. R., Clausing, D. (1988). The house of quality, Harvard Business Review, 66(3), 63-73.

[24] Ho, W. (2008). Integrated analytic hierarchy process and its applications - A literature review, European Journal of Operational Research 186, 211-228, DOI: 10.1016/j.ejor.2007.01.004

[25] Ho, W., He, T., Lee, C. K. M., Emrouznejad, A. (2012). Strategic logistics outsourcing: An integrated QFD and fuzzy AHP approach, Expert Systems with Applications 39, 10841-10850, DOI: 10.1016/j.eswa.2012.03.009

[26] Isaai, M. T., Kanani, A., Tootoonchi, M., Afzali, H. R. (2011). Intelligent timetable evaluation using fuzzy AHP, Expert Systems with Applications 38, 3718-3723, DOI> 10.1016/j.eswa.2010.09.030

[27] Ju, J.-M., Hwang, S.-G. (2004). A study on supplier evaluation and selection method based on dependence, Journal of Advanced Computational Intelligence and Intelligent Informatics 8 (4) 415-420.

[28] Karsak, E. E., Sozer, S., Alptekin, S. E. (2002). Planning in quality function deployment using a combined analytic network process and goal programming approach. Computers \& Industrial Engineering, 44, 171-190, DOI: 10.1016/S0360-8352(02)00191-2

[29] Khademi-Zare, H., Zarei, M., Sadeghieh, A., Owlia, M.S. (2010). Ranking the strategic actions of Iran mobile cellular telecommunication using two models of fuzzy QFD, Telecomunications Policy 34, 747-759, DOI: 10.1016/j.telpol.2010.10.001

[30] Kilincci, O., Onal, S. A. (2011). Fuzzy AHP approach for supplier selection in a washing machine company, Expert Systems with Applications 38, 9656-9664, DOI: 10.1016/j.eswa.2011.01.159

[31] Kuo, T.-C., Wu, H.-H., Shieh, J.-I. (2009). Integration of environmental considerations in quality function deployment by using fuzzy logic, Expert Systems with Applications 36, 7148-7156, DOI: 10.1016/j.eswa.2008.08.029

[32] , C.K., , H. (2003). Determining the importance weights for the customer requirements in QFD using a fuzzy AHP with an extent analysis approach, IIE Transactions, , pages 619-626, DOI: $10.1080 / 07408170304355$ 
[33] , C.K., , H. (2006). A fuzzy AHP approach to the determination of importance weights of customer requirements in quality function deployment, , Volume 13, , pp 367-377, DOI: 10.1023/A:1019984626631

[34] Larimian, T., Zarabadia, Z.S.S., Sadeghi, A. (2013). Developing a fuzzy AHP model to evaluate environmental sustainability from the perspective of Secured by Design scheme-A case study, Sustainable Cities and Society 7, 25-36, DOI: 10.1016/j.scs.2012.10.001

[35] Lee, Y. C., Sheu, L. C., Tsou, Y. G. (2008). Quality function deployment implementation based on Fuzzy Kano model: An application in PLM system, Computers \& Industrial Engineering, 55, 48-63, DOI: 10.1016/j.cie.2007.11.014

[36] Liang, G.S. (2010). Applying fuzzy quality function deployment to identify service management requirements for customer quality needs, Quality and Quantity, 44(1), DOI: 10.1007/s11135-008-9178-7

[37] Luo, X. G., Tang, J. F., Wang, D. W. (2008). An optimization method for components selection using quality function deployment, The International Journal of Advanced Manufacturing Technology, 39, 158167, DOI: 10.1007/s00170-007-1206-6

[38] Nepal, B., Yadav, O.P., Murat, A. (2010). A fuzzy-AHP approach to prioritization of CS attributes in target planning for automotive product development, Expert Systems with Applications 37, 6775-6786, DOI: 10.1016/j.eswa.2010.03.048

[39] Ni, M., Xu X., Deng S. (2007). Extended QFD and data-mining-based methods for supplier selection in mass customization, International Journal of Computer Integrated Manufacturing 20 (2-3) 280-291, DOI: 10.1080/09511920601150651

[40] Rezaei, J., Ortt, R. (2013). Multi-criteria supplier segmentation using a fuzzy preference relations based AHP, European Journal of Operational Research 225, 75-84, DOI: 10.1016/j.ejor.2012.09.037

[41] Saaty, T.L. (1977). A scaling method for priorities in hierarchical structures, Journal of Mathematical Psychology 15, 234-281, DOI: 10.1016/0022-2496(77)90033-5

[42] Saaty, T.L. (1980). The Analytic Hierarchy Process, McGraw-Hill, New York

[43] Saaty, T.L. (1988). The Analytic Hierarchy Process, revised edn, University of Pittsburgh Press, Pittsburgh, PA

[44] Saaty, T.L. (2008). Decision making with the analytic hierarchy process, International Journal of Services Sciences 1 (1), 83-98.

[45] Sen, C.G., Baracli, H. (2010). Fuzzy quality function deployment based methodology for acquiring enterprise software selection requirements, Expert Systems with Applications 37, 3415-3426, DOI: 10.1016/j.eswa.2009.10.006

[46] Sohn, S.Y., Choi, I.S. (2001). Fuzzy QFD for supply chain management with reliability consideration, Reliability Engineering \& System Safety 72 (3), 327-334, DOI: 10.1016/S0951-8320(01)00022-9

[47] Wang, L., Juan, Y.-K., Wang, J., Li K.-M., Ong, C. (2012). Fuzzy-QFD approach based decision support model for licensor selection, Expert Systems with Applications 39, 1484-1491, DOI: 10.1016/j.eswa.2011.08.037

[48] Wang, X., Chan, H.K., Yee, R., Rainey, I.D. (2012). A two-stage fuzzy-AHP model for risk assessment of implementing green initiatives in the fashion supply chain, International Journal of Production Economics 135, 595-606, DOI: 10.1016/j.ijpe.2011.03.021

[49] Yang, Y.Q., Wang, S.Q., Dulaimi, M., Low, S.P. (2003). A fuzzy quality function deployment system for buildable design decisionmakings, Automation in Construction 12, 381-393, DOI: 10.1016/S09265805(03)00002-5

[50] Zadeh, L.A. (1965). Fuzzy sets. Information and Control 8, 338-353.

[51] Zadeh, L.A. (1973). The concept of a linguistic variable and its application to approximate reasoning. Memorandum ERL-M 411 Berkeley

[52] Zheng, G., Zhu, N., Tian, Z., Chen, Y., Sun, B. (2012). Application of a trapezoidal fuzzy AHP method for work safety evaluation and early warning rating of hot and humid environments, Safety Science 50, 228-239, DOI: 10.1016/j.ssci.2011.08.042

[53] , A., , L. (2012). Simulation based fuzzy TOPSIS approach for group multi-criteria supplier selection problem, , , Pages 507-519, DOI: 10.1016/j.engappai.2011.10.012

\section{ACKNOWLEDGMENT}

This paper is part of a project supported by the Ministry of Education, Science and Technological Development of the Republic of Serbia, under the title TR 32016 - Innovative electronic components and systems based on inorganic and organic technologies, embedded in goods and consumer products. 


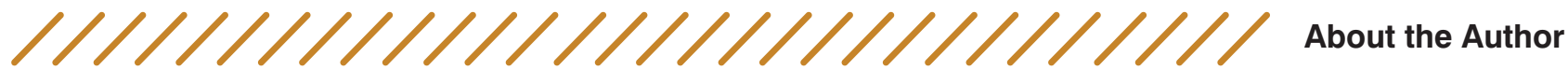

Bojana Jovanović Iritel a.d. Belgrade, Batajnicki put 23, Serbia Bojana.jovanovic.123@gmail.com

Bojana Jovanović is a PhD candidate at the Faculty of organizational sciences, Department of Management, University of Belgrade. The author works as a research associate at the Institute for telecommunications and electronics Iritel a.d. Belgrade, as a lecturer at the Education center Institution and as a consultant at various projects for CE marking of products.

\section{Boris Delibašić}

University of Belgrade, Faculty of organizational sciences, Serbia boris.delibasic@fon.bg.ac.rs

Boris Delibašić is profesor at the Faculty of Organizational Sciences, University of Belgrade. He obtained his PhD in 2007 in Business Decision-Making. His main research areas are decision support Systems, business intelligence, data mining, and decision theory. 